\title{
Pengaruh Perhatian Orangtua Terhadap Motivasi Belajar Siswa
}

\author{
Nolinia Zega, ${ }^{1 *}$ Efvi Noyita, ${ }^{2}$ Haposan Simanjuntak ${ }^{3}$ \\ Prodi PAK, STT Real Batam \\ Prodi PAK, STT Real Batam \\ Prodi PAK, STT Real Batam \\ noliniazega53@gmail.com
}

\begin{abstract}
This study aims to describe the influence of parental attention on student motivation. Thus, in this paper the authors use research techniques. To achieve these objectives researchers used a quantitative approach with a survey research design. There are two formulations of problems that lead the implementation of this research, namely: Does the attention of parents positively influence student motivation? Research data obtained by researchers through, namely: used research methods in the form of data collection. Data collection methods are questions in what way and how the required data can be collected and the final results of research used in a systematic and logical structured method.
\end{abstract}

Keywords: Influence, Attention, Parents, Motivation, Learning

\begin{abstract}
Abstrak
Penelitian ini bertujuan untuk mendeskripsikan pengaruh perhatian orangtua terhadap motivasi belajar siswa. Dengan demikian, dalam tulisan ini penulis menggunakan teknik penelitian. Untuk mencapai tujuan tersebut peneliti menggunakan pendekatan kuantitatif dengan rancangan penelitian survey. Ada dua rumusan masalah yang menuntun pelaksanaan penelitian ini, yaitu: Apakah perhatian orang tua berpengaruh secara positif terhadap motivasi belajar siswa? Data penelitian diperoleh peneliti melalui cara, yaitu: digunakan metode penelitian dalam bentuk pengumpulan data. Metode pengumpulan data adalah pertanyaan dengan cara apa dan bagaimana data yang diperlukan dapat dikumpulkan dan hasil akhir penelitian digunakan dalam metode tersusun secara sistematis dan logis.
\end{abstract}

Kata kunci: Pengaruh, Perhatian, Orangtua, Motivasi, Belajar

\section{PENDAHULUAN}

Menurut Bomo Walgito dalam Muthmainnah motivasi merupakan keadaan dalam diri individu atau organisme yang mendorog perilaku kearah tujuan. ${ }^{1}$ Menurut winkel keseluruhan daya penggerak psikis dalam diri siswa yang menimbulkan kegiatan belajar dan menjamin kelangsungan belajar itu demi tercapainya tujuan disebut motivasi belajar. ${ }^{2}$ Peningkatan mutu setiap jenjang dan jenis pendidikan merupakan titik berat dari pembangunan pendidikan. Untuk itu siswa diharapkan keaktifan dan kekreatifan dalam

\footnotetext{
${ }^{1}$ Muthmainnah, "Peran Orang Tua Dalam Menumbuhkan Pribadi Anak Yang Androgynius Melalui Kegiatan Bermain," Jurnal Pendidikan Anak 1, no. 1 (2012): 103-112.

${ }^{2}$ W S Winkel, Psikologi Pengajaran (Jakarta: Grasindo, 2005). 52
} 
setiap proses belajar mengajar, serta termotivasi untuk aktif dalam menjawab pertanyaan, bertanya, serta termotivasi mengerjakan tugas, khususnya untuk siswa yang jauh dari orangtua. $^{3}$

Di mana siswa khususnya yang sudah jauh dari orangtua kebanyakan malas dalam belajar tanpa dukungan dari orangtua baik dari segi komuniklasi maupun dari segi finansial. Jika siswa tidak berbuat sesuatu yang seharusnya dikerjakan pada setiap pembelajaran, perlu diteliti sebab akibatnya, karena hal itu bisa berdampak pada perubahan energi untuk melakukan sesuatu. Dalam keadaan seperti hal tersebut perlu ditumbuhkan motivasi pada diri siswa tersebut.

Wina Sanjaya dalam Amna Emda mengatakan motivasi merupakan salah satu aspek dinamis dalam sebuah pembelajaran. Seorang siswa yang kurang berprestasi tidak selalu dipengaruhi oleh kemampuan yang kurang, tetapi karena kurangnya motivasi siswa untuk belajar. Unsur Motivasi terkadang terlupakan oleh guru dalam proses pembelajaran tradisonal yang menggunakan pendekatan yang ekspositori. ${ }^{4}$

Setiap siswa memiliki motivasi sendiri-sendiri dalam mengikuti pembelajaran siswa, bahwa semua siswa diharapkan mampu menyelesaikan tanggung jawabnya sebagai siswa. Salah satu faktor pendukung dalam motivasi belajar anak ialah peran orang tua. Dalam basis pendidikan, keluarga merupakan basis pendidikan yang pertama dan utama. Keadaan keluarga yang harimonis dan Bahagia dapat melahirkan anak atau generai penerus yang baik. Peran orang tua yang seharusnya adalah sebagai orang pertama dalam meletakkan dasar-dasar pendidikan terhadap anak-anaknya. ${ }^{5}$ Peran orangtua dalam memotivasi anaknya juga diperlukan, karena orangtua adalah tempat di mana anak bisa tumbuh kembang dan berinteraksi dengan lingkungan. Orangtua selalu berada dan menjadi tempat cerita dengan anak, kaitannya dalam proses memotivasi anaknya dalam meningkatkan belajarnya. Motivasi sangat diperlukan dalam proses belajar, karena jika seseorang tidak memilki motivasi akan mengalami kesulitan dalam melakukan aktivitas belajar.

Baik buruknya prestasi yang dicapai oleh anak akan mempengaruhi perkembangan dan pendidikan selanjutnya. Oleh karena itu dukungan orangtua penting dalam kegiatan belajar anak. Dengan adanya dukungan orangtua dalam belajar, membuat anak akan lebih giat dan lebih bersemangat. Dengan dukungan tersebut ia tahu bahwa bukan hanya dirinya sendiri saja yang berkeinginan untuk maju, akan tetapi orangtuanya pun demikian. ${ }^{6}$

\footnotetext{
${ }^{3}$ Rosnita Temba Kagu, "Implementasi Pembelajaran Konstruktivisme Terhadap Motivasi Belajar Kristen” (STT REAL, 2018). 2

${ }^{4}$ Amna Emda, "Kedudukan Motivasi Belajar Siswa Dalam Pembelajaran," Jurnal Lantanida 5, no. 2 (2017): 93-196.

${ }^{5}$ Hermus Hero and Maria Ermalinda Sni, "Peran Orang Tua Dalam Meningkatkan Motivasi Belajar Siswa Kelas V Di Sekolah Dasar INPRES ILIGETANG,” Jurnal Riset Pendidikan Dasar 01 (2018): 129-139.

${ }^{6}$ Nanda Alfian Mahardhika et al., "Dukungan Orangtua Terhadap Motivasi Berprestasi Siswa SKOI Kalimantan Timur Dalam Mengikuti Pembelajaran Pendidikan Jasmani Parental Support for the Achievement
} 
Motivasi belajar dapat timbul karena faktor instrinsik, berupa keinginan berhasil, kebutuhan belajar untuk cita-cita masa depan, dan sedangkan faktor ekstrinsik adalah adanya penghargaan dalam belajar. Terkait dukungan orangtua Fredy Simanjuntak menjelaskan mengenai pola hubungan yang memiliki pengaruh terhadap motivasi, pola hubungan merupakan pusat dari kekristenan itu sendiri yang menjadikan hukum terutama yaitu mengasihi Tuhan Allah setara dengan mengasihi sesama manusia. Allah menjadikan keluarga sebagai tempat untuk manusia dapat belajar saling mengasihi. ${ }^{7}$

Di dalam penelitian ini peneliti hanya berfokus pada dua faktor yaitu faktor dukungan keluarga (faktor eksternal) dan faktor motivasi belajar siswa (faktor internal). Motivasi bisa muncul dari diri individu (internal) maupun dari luar individu (eksternal). Setiap individu merasa senang apabila diberikan penghargaan dan dukungan atau motivasi. Motivasi menjadikan individu menjadi semangat dalam mencapai tujuan. Motivasi diberikan agar anak selalu berusaha mempertahankan dan meningkatkan apa yang sudah dicapai. Apabila anak belum berhasil, maka motivasi dapat membuat anak pantang menyerah dan mau mencoba lagi. ${ }^{8}$

Menurut Irwan Prayitno seorang Psikologi dalam Harmani, anak mengenal dunia disekitarnya melalui bicara orang tua dan sekitarnya. ${ }^{9}$ Menurut Fadillah dalam Novrinda keluarga merupakan lingkungan awal bagi anak, segala tingkah laku kedua orangtua akan diconton dan muncul pada diri dalam perkembangannya. Selain itu, orangtua sebagai salah satu pihak yang bertanggung jawab dalam pendidikan sangat besar pengaruhnya terhadap perkembangan pendidikan anak. Orangtua perlu terus-menerus untuk mendorong, membimbing, memotivasi dan memfasilitasi supaya tercapai pendidikan yang baik bagi anak. $^{10}$ Pentingnya peranan orang tua ini didasarkan pada kenyataan bahwa orang tua adalah orang yang paling pertama dilihat dan dikenal anak-anak. Anak-anak merupakan tanggung jawab orang tua dan, karena itu, orang tua harus berusaha dengan segenap tenaga memberikan yang terbaik untuk pendidikan anak-anaknya. Dukungan orang tua kepada anak-anaknya dapat tercurah melalui banyak bentuk dan cara.

\section{METODE}

Untuk mendapatkan kebenaran sebagaimana dinyatakan dalam tujuan penelitian, maka digunakan metode penelitian dalam bentuk pengumpulan data. Metode pengumpulan data adalah pertanyaan dengan cara apa dan bagaimana data yang diperlukan dapat

Motivation of SKOI Students in East Kalimantan in Attending Physical Education Learning" 14, no. 2 (2018): $62-$ 68.

${ }^{7}$ Fredy Simanjuntak, "Problematika Disorganisasi Dan Disharmonisasi Keluarga," in Keluarga Yang Misioner, 2018.

${ }^{8}$ Muthmainnah, "Peran Orang Tua Dalam Menumbuhkan Pribadi Anak Yang Androgynius Melalui Kegiatan Bermain.”

${ }_{9}^{9}$ Harmaini, “Keberadaan Orang Tua Bersama Anak," Jurnal Psikologi 9, no. 2 (2013).

${ }^{10}$ Novrinda, Nina Kurniah, and Yulidesni, "Peran Orangtua Dalam Pendidikan Anak Usia Dini Ditinjau Dari Latar Bekajang Pendidikan,” Jurnal Potensia 2, no. 1 (2017): 39-46. 
dikumpulkan dan hasil akhir penelitian digunakan dalam metode penelitian tersusun secara sistematis dan logis. Di dalam penelitian ini, penulis menggunakan metode penelitian kualitatif.

\section{HASIL DAN PEMBAHASAN}

Menurut Otieli Harefa, Orangtua yang bertanggungjawab dan mengasihi anakanaknya terus berusaha untuk memberikan keteladanan hidup bagi anak-anaknya. Ketika orangtua mampu mengaplikasikan ajaran Firman Tuhan dalam kehidupan rumah tangganya, maka anak-anak akan memiliki suatu kebenaran yang menuntun mereka dalam pertumbuhan yang baik. ${ }^{11}$ Berikut ini merupakan pendapat ahli tentang wujud dukungan orangtua kepada anak-anaknya adalah sebagai berikut :

1. Werang mengemukakan beberapa wujud dukungan orang tua kepada anak-anaknya sebagai berikut. Pertama, dukungan yang bersifat psikis-spiritual. Dengan dukungan psikis-spiritual dimaksudkan upaya yang dilakukan orang tua dalam mengerahkan dan mengarahkan seluruh daya psikis-spiritual yang ada padanya untuk kemaslahatan hidup anak-anaknya. Perhatian psikis-spiritual antara lain mewujud dalam aktivitas-aktivitas seperti berikut :

a. Mendoakan anak-anaknya siang dan malam

b. Mendorong anak-anaknya untuk selalu tekun dalam berdoa dan belajar

c. Mendorong anak-anaknya untuk terlibat aktif dalam berbagai kegiatan sosial keagamaan

d. mendorong anak-anak untuk selalu menjaga kebersihan dan kesehatan tubuh

e. Menanamkan sikap optimistis dalam diri anak-anaknya dengan sebuah keyakinan bahwa Tuhan tidak pernah membiarkan makhluk ciptaannya terus berada dalam 'kubangan' ketidakmampuan

f. Mendengarkan secara seksama semua keluh-kesah anak-anaknya terlebih yang berhubungan dengan masalah belajar, cinta, dan pergaulan

g. Bersama anak-anak memikirkan jalan keluar terbaik untuk masalah yang sedang dihadapi. Kedua, dukungan fisik-material. Dengan dukungan fisik-material dimaksudkan upaya yang dilakukan orang tua dalam mengerahkan dan mengarahkan seluruh daya fisik-material yang ada padanya untuk kemaslahatan hidup anakanaknya. Perhatian fisik-material antara lain mewujud dalam aktivitas-aktivitas seperti berikut :

a. Menyediakan makanan dan minuman dengan nutrisi yang cukup untuk anakanaknya

b. Menyediakan tempat kediaman yang layak bagi anak-anak

c. Menyediakan pakaian yang cukup untuk anak-anak

d. Menjaga tempat kediaman selalu berada dalam kondisi bersih dan sehat

${ }^{11}$ Otieli Harefa, “Keluarga Sebagai Pusat Pembentukan Rohani Anak," Real Didache 1, no. 1 (2016): 1-22. 
e. Menyediakan tempat belajar di rumah untuk anak-anak

f. Menyediakan penerangan yang cukup di rumah untuk kegiatan belajar anak-anak

g. Menyediakan buku-buku pelajaran untuk anak-anak belajar di rumah

h. Menyediakan peralatan belajar yang memadai untuk anak-anak

i. menyediakan perlengkapan berdoa untuk anak-anak

j. Menyediakan obat-obatan di rumah untuk anak-anak

k. Mengantar dan menjemput anak-anak ke dan dari sekolah

1. Menemani anak-anak pada acara-acara sekolah yang mengharuskan kehadiran orang tua

m. Menemani anak-anak berekreasi dari kepenatan hidup harian. ${ }^{12}$

Kata motivasi berasal dari bahasa Latin movere yang berarti menggerakkan. Motivasi merupakan sebuah istilah umum yang mencakup keseluruhan kekuatan atau dorongan yang berupa keinginan dan kebutuhan untuk mencapai tujuan dari suatu pekerjaan. ${ }^{13}$ Sardiman mengartikan kata 'motivasi' sebagai keseluruhan daya penggerak di dalam diri seseorang yang memunculkan dan menjamin keberlangsungan sebuah kegiatan serta memberikan arah kepada kegiatan tersebut sehingga tujuan yang dikehendaki dapat tercapai. ${ }^{14}$ Motivasi sebagai keinginan yang terdapat pada seseorang yang mendorongnya untuk berusaha atau melakukan tindakan tertentu demi memenuhi kebutuhan hidup. Menurut Werang merinci tiga elemen pokok yang terkandung di dalam setiap motivasi sebagai berikut :

a. Usaha yaitu orang yang bermotivasi tinggi akan berusaha dengan segenap daya dan tenaga untuk menghasilkan suatu karya yang bermutu

b. Tujuan yaitu setiap tujuan mengandung harapan dan cita-cita yang ingin dicapai. Tujuan yang hendak dicapai memberikan arah kepada perilaku dan perjuangan setiap manusia. Rumusan tujuan yang jelas akan menjadi daya tarik yang menggerakkan dan sekaligus mengarahkan setiap aktivitas dan perilaku seseorang dan

c. Kebutuhan yaitu kebutuhan menunjuk kepada kondisi internal yang menyebabkan sesuatu yang nampak menarik. Kebutuhan menjadi daya dorong bagi setiap individu untuk melakukan suatu tindakan atau pekerjaan yang diyakini dapat memberikan kepuasan terhadap kebutuhan tersebut. ${ }^{15}$

\section{KESIMPULAN}

Setiap siswa memiliki motivasi sendiri-sendiri dalam mengikuti pembelajaran siswa, bahwa semua siswa diharapkan mampu menyelesaikan tanggung jawabnya sebagai

${ }^{12}$ Zem Santo, Martino Minok Kimbay, and Basilius Redan Werang, "Pengaruh Dukungan Orang Tua Dan Motivasi Belajar Terhadap Prestasi Belajar Bahasa Indonesia Siswa SD YPPK Maria Fatimah Merauke," Jurnal Magistra 5 (2018): 52-63.

${ }^{13}$ Basilius Redan Werang, Belajar Dan Pembelajaran. (Malang: Elang Emas, 2011).90

${ }^{14}$ Sardiman A M, Interaksi Dan Motivasi Belajar-Mengajar (Jakarta: PTRaja Grafindo Persada, 2006). 73

${ }^{15}$ Santo, Kimbay, and Werang, "Pengaruh Dukungan Orang Tua Dan Motivasi Belajar Terhadap Prestasi Belajar Bahasa Indonesia Siswa SD YPPK Maria Fatimah Merauke." 
siswa. Peran orangtua dalam memotivasi anaknya juga diperlukan, karena orangtua adalah tempat di mana anak bisa tumbuh kembang dan berinteraksi dengan lingkungan. Dukungan orangtua memilki pengaruh psikologis yang besar terhadap kegiatan belajar anak. Dengan adanya dukungan orangtua, anak akan lebih giat dan lebih bersemangat dalam belajar karena ia tahu bahwa bukan dirinya sendiri saja yang berkeinginan untuk maju, akan tetapi orangtuanya pun demikian. Motivasi belajar dapat timbul karena faktor instrinsik, berupa keinginan berhasil, kebutuhan belajar untuk cita-cita masa depan, dan sedangkan faktor ekstrinsik adalah adanya penghargaan dalam belajar.

\section{KEPUSTAKAAN}

Emda, Amna. "Kedudukan Motivasi Belajar Siswa Dalam Pembelajaran." Jurnal Lantanida 5, no. 2 (2017): 93-196.

Harefa, Otieli. "Keluarga Sebagai Pusat Pembentukan Rohani Anak." Real Didache 1, no. 1 (2016): 1-22.

Harmaini. "Keberadaan Orang Tua Bersama Anak." Jurnal Psikologi 9, no. 2 (2013).

Hero, Hermus, and Maria Ermalinda Sni. "Peran Orang Tua Dalam Meningkatkan Motivasi Belajar Siswa Kelas V Di Sekolah Dasar INPRES ILIGETANG.” Jurnal Riset Pendidikan Dasar 01 (2018): 129-139.

Kagu, Rosnita Temba. "Implementasi Pembelajaran Konstruktivisme Terhadap Motivasi Belajar Kristen." STT REAL, 2018.

M, Sardiman A. Interaksi Dan Motivasi Belajar-Mengajar. Jakarta: PTRaja Grafindo Persada, 2006.

Mahardhika, Nanda Alfian, Jeane Betty, Kurnia Jusuf, and Galih Priyambada. "Dukungan Orangtua Terhadap Motivasi Berprestasi Siswa SKOI Kalimantan Timur Dalam Mengikuti Pembelajaran Pendidikan Jasmani Parental Support for the Achievement Motivation of SKOI Students in East Kalimantan in Attending Physical Education Learning" 14, no. 2 (2018): 62-68.

Muthmainnah. "Peran Orang Tua Dalam Menumbuhkan Pribadi Anak Yang Androgynius Melalui Kegiatan Bermain." Jurnal Pendidikan Anak 1, no. 1 (2012): 103-112.

Novrinda, Nina Kurniah, and Yulidesni. "Peran Orangtua Dalam Pendidikan Anak Usia Dini Ditinjau Dari Latar Bekajang Pendidikan.” Jurnal Potensia 2, no. 1 (2017): 3946.

Santo, Zem, Martino Minok Kimbay, and Basilius Redan Werang. "Pengaruh Dukungan Orang Tua Dan Motivasi Belajar Terhadap Prestasi Belajar Bahasa Indonesia Siswa SD YPPK Maria Fatimah Merauke.” Jurnal Magistra 5 (2018): 52-63.

Simanjuntak, Fredy. "Problematika Disorganisasi Dan Disharmonisasi Keluarga." In Keluarga Yang Misioner, 2018.

Werang, Basilius Redan. Belajar Dan Pembelajaran. Malang: Elang Emas, 2011. Winkel, W S. Psikologi Pengajaran. Jakarta: Grasindo, 2005. 